\title{
Talatalanoa as ongoing complex conversations and negotiation of practice in higher education
}

\author{
David Taufui Mikato Fa'avae
}

University of Waikato

Sonia M. Fonua

\section{University of Auckland}

Higher education is a site where diverse cultures and knowledges intersect. Engaging in complex conversations is necessary for educators and academics to confront and negotiate differences, especially in areas they may not be overly familiar with. Negotiating complex conversations is difficult, time consuming, risky, yet rewarding, particularly if shifts in the understanding or valuing of relational engagement and practice. In this article, as a Tongan teacher educator and Pāpālangi (of European heritage/s) educator, we critically reflect on our work in transforming learning and engagement contexts that predominantly ignore expressions of Pacific Indigenous knowledge and Tongan ways of being. Through our collaborative talatalanoa (ongoing conversations) we demonstrate the value of negotiating complex conversations in higher education and particular aspects to consider when instigating them.

Keywords: talatalanoa, complex conversations, vulnerability, Pacific Indigenous knowledge, higher education

\section{Introduction}

Complex yet confronting conversations are linked to competing knowledges in higher education that often privileges dominant Western epistemes and systems and marginalises Pacific Indigenous knowledge systems. Higher education encourages the pursuit of new knowledge and excellence and the "academic" is perceived as the knowledge expert. This can complicate the initiation of conversations linked to what they do not know. To admit not knowing can trigger vulnerability, particularly in the neoliberal setting focused heavily on competition, ranking, and individual outputs. Articulating our vulnerabilities is a critical practice and can lead to emotional "release [and] emancipation" (Havea, 2020, p. 1). Whether David is educating teachers or Sonia is working with science lecturers, we both acknowledge and address the tensions, benefits and considerations of our non-indigenous audience within higher education (Fonua, 2020).

We draw on Thaman's (1995) definition of culture as "the way of life of a discrete group of people. It includes language together with an associated body of accumulated knowledge, understandings, skills, beliefs and values" (p. 723). This definition speaks to Pacific Indigenous knowledge grounded in the Moana (Oceania) which we position in this paper as marginalised knowledge in higher education. We utilise the capital "I" in Indigenous within this paper because it refers to knowledge rooted in the Moana. We, the authors, reflect on our experiences of the devaluing of Indigenous knowledge and practice 
in higher education and how we negotiate such complex conversations. The complex conversations are about our experiences as a Tongan and Pāpālangi (of European heritage/s) of the devaluing of Pacific Indigenous knowledge and practice within university settings in New Zealand.

\section{Talatalanoa as method}

Talatalanoa is a derivative of talanoa. When deconstructed, "tala" means to tell, to story, or conversation, and "noa" means anything, nothing, or something. The repetition of "tala" within "tala-tala-noa" emphasises an ongoing process of storying, dialogue, or conversation (Fa'avae, 2021). It is used when Tongan people engage in critical and complex conversations with no expected outcome or solution other than providing a space to openly share their thoughts and concerns. We employ talatalanoa as a Tongan method linked to ongoing dialogue and conversation (Fa'avae, 2021). Within talatalanoa engagement, interactions are "governed by the principles of faka'apa'apa (respect), loto toka'i (care), and loto fiefoaki (generosity), so that we are able to share our differently similar views, and confront oppressive structures with marginalised voices in a mainstream discourse" (Fa'avae, Tecun, \& Siu'ulua, 2021, p. 7). We deliberately utilise talatalanoa to capture and unpack the nature of complex conversations in higher education, as well as its risks and rewards. Talatalanoa requires time and commitment. This paper demonstrates an ongoing conversation between Sonia and David; a Pāpālangi educator and a Tongan teacher educator within university settings, since our presentation in the 'Cancelled Conferences Seminar Series' organised by the Research Deans across universities in New Zealand. We also acknowledge the virtual space, through digital technology, as the context and tools that extended our talatalanoa.

Four questions guide our reflections and talatalanoa based on what it means to confront complex conversation in higher education spaces to do with the place of Pacific Indigenous knowledge and meaningful engagement within higher education.

\section{Confronting complex conversations}

What do complex conversations for Pacific and non-Pacific educators and academics look like in Higher Education?

\section{David}

Complex conversations, though hard, often stem from feelings of vulnerability. They can be linked to competing knowledge systems, values, and beliefs that manifest in our actions and conversations in higher education. Universities value the pursuit of knowledge creation, regularly seen as an integral part of the intellectual enterprising of academic knowledge, processes, and services. For Pacific Indigenous people, we enter the higher education space bringing and drawing from knowledge that doesn't fit into that space, leaving Pacific people feeling vulnerable and struggling to move and engage in these conversations. The higher education space can't avoid the neoliberal agenda that drives universities and their practices, however, being part of a learning community, we can be open about our feelings of vulnerability, and negotiate and mediate the challenges. This talatalanoa with Sonia is an opportunity to unravel what it means to work through the 
complex yet critical conversations from our positionalities as a Tongan and a Pāpālangi within university settings.

\section{Sonia}

I acknowledge David speaks from an Indigenous Pacific/Moana perspective, while I am a non-Indigenous Pacific person, born and raised in Aotearoa New Zealand. I often find myself in conversations where the complexity includes negotiating what I know and feel I can share, without over-stepping into positioning myself as an 'expert' regarding Indigenous knowledges, which I am definitely not. However, I do recognise that Pāpālangi are the primary audience and participants in these conversations, therefore I can speak in a particular way, using my experience to understand their hesitations and reservations, where I can push, and which language to use. The burden of these conversations should not rest on Pacific Indigenous alone but be aided and shared by those who can 'translate' policies and procedures within the university and academic system that marginalises Pacific Indigenous knowledge and practice. Complex conversations are necessarily about making visible the competing knowledge systems and participating in open, generous, and caring conversations about ways to disrupt university systems and processes that are conducive to successful outcomes for Pacific people. This is one of my responsibilities as an ally to David and my Pacific colleagues in New Zealand.

Why are complex conversations necessary and so difficult to have?

\section{David}

Sonia is a friend and colleague. I first connected with her through other Tongan and Pacific friends. Her husband, Fire, who is of Tongan ancestry shares similar passion about reviving Tongan ways of knowing and being. Her sons, Pitasoni and Havea Hikule'o, like my wife 'Elenoa and son Daniel, share similar mixed Tongan and Pāpālangi identities. Although Sonia has faced challenges from other Pāpālangi and Pacific/Moana scholars, she chooses to remain and be present so that she can learn how to nurture tauhi vā (maintain respectful relations) because it is valued by family and Tongan and Pacific people around her. As articulated by Associate Professor Tamasailau Sualii-Sauni (2017), Pacific-led work and research helps to make sense of our vā relational connections with Pāpālangi and other non-Pacific people in Aotearoa higher education. I appreciate Sonia's commitment to supporting Pacific-led work and research and how she continues to be "present" when working with research concerns and endeavours for our Tongan and Pacific communities and students in higher education in Aotearoa and in the Moana. $V \bar{a}$ ethics is a way for complex conversations and negotiations to take place, and ignoring the principles of tauhi $v \bar{a}$, feveitoka'i'aki (generosity and care) and 'ofa (compassion) can perpetuate nongenerative possibilities as we move through higher education together.

How we both position and relate ourselves to Western and Pacific Indigenous knowledge is an ontological and epistemological concern because it shapes how we perceive and understand what is real and truthful, and what constitutes knowledge and meaning within higher education. Sonia locates and relates herself across cultural diversity; this can result in feelings of vulnerability. Although she is married to Fire and has two Tongan sons, her relational positionality as a Pāpālangi and learning to navigate and mediate her sense of belonging as well as meaning-making in ways that embrace and protect Tongan and Pacific knowledge and practice is always going to be challenging. 
What I appreciate about Sonia is that she is "present" and chooses to remain part of our community, even when things are challenging. For me, when locating and positioning myself in relation to Pāpālangi as well as Māori, particularly within the context of bicultural education between Māori and non-Māori and honouring Te Tiriti o Waitangi, such attempts to make connections can be difficult to do and make sense. However, such complex conversations are necessary for growth and development, and essential for any attitude and behavioural shifts to take place (Bishop, Berryman, Cavanagh, \& Teddy, 2007).

One of my responsibilities as a lecturer in Pacific Education at the University of Waikato is to help make sense of, develop, and implement Tapasā into the professional and cultural competencies of teachers within the Initial Teacher Education (ITE) programmes. Some ITE students in my classes roll their eyes, yawn, or avoid eye contact whenever I talk about Indigenous Pacific knowledge and culturally sustainable practice, which I found confronting. The essence of Tapas $\bar{a}$ lies in teachers' capacity and competency to appreciate and embrace difference and value relational connections because it matters and is at the heart of how Pacific people make sense of their world including learning (Siope, 2013).

\section{Sonia}

Recent discussions with Pāpālangi around the difference in the role of teachers vs. lecturers, particularly expectations of how their practice connects with students, raised concerns around the sharing of personal information and the risk of forming relationships with students. As Thaman (1995) highlights, to understand and participate in crosscultural relationships we must understand how culture informs each partner in the relationship. In Pacific contexts, the honouring of reciprocal connections is prioritised. In university settings, building relationships, or acts such as discussing culturally sustainable practice like David does with his students, raise tensions between vulnerability and the prioritisation of content and best practice (Fonua, 2020). Tapas $\bar{a}$ expects the establishment of collaborative and respectful relationships; unfortunately, most science educators in higher education prioritise time on content over relationship building.

Asking people to shift their behaviour can trigger all sorts of reactions, namely discomfort. But we know when someone holds all the power and the agency, it's easy to dismiss the need to change because it does not suit them to do so, perhaps it's not explicitly in their job description, or they do not feel it is a safe thing for them to do. Yet, this is individualistic thinking, not considering the collective or the best way to share knowledge. If we want to negotiate practice, be able to discuss what is best practice and how to enact it in ways that maintain the mana of Pacific or Tongan people, then talatalanoa conversations guided by its core principles linked to faka'apa'apa (respect), loto toka'i (care), and loto-fie-foaki (generosity) are absolutely necessary or the inequitable, inappropriate and meritocratic approach will prevail.

\section{David}

To make sense of the vulnerabilities and uncomfortableness which Sonia raises, I turn to Tongan language and concepts. Talatalanoa embraces relationality and connection at the core of critical engagement. But to talatalanoa in ways that are guided by the generosity of spirit and care, as Tamasailau Suaalii-Sauni (2017) often reminds Pacific early career academics to consider, is to acknowledge the discomforts. As Sonia notes, taking a 
deliberate shift to re-position thinking and perspective is significant. The move to reposition or re-calibrate one's position inevitably changes one's point of reference and points of relational connection. To shift requires a departure from a place of comfort and letting go of familiar knowledge and practice. This therefore requires new knowledge or practice to replace previous attitudes and behaviours. This can be risky yet rewarding if we prioritise open talatalanoa.

\section{Sonia}

I am aware that when I am enabled to work with Tongan concepts, it is mainly at the interpretation level. Because it is not part of my embedded lived experience, I spend time and listen to how Tongan scholars like 'Ema Wolfgramm-Foliaki including David, unpack the cultural and ethical grounding of the ideas. I think it is important to acknowledge that while David is speaking about teachers explicitly learning about Pacific aspects in their curriculum and practice through Tapasā, complex conversations should not be limited to such spaces. In my work, the graduate profile acknowledges specific discipline knowledge, critical thinking skills and independence and integrity, but also being able to communicate with, and maintain respect for diverse audiences. This includes with Pacific peoples. I would have to ask, if practices are not challenged, contested and shifted, how will students know how to do this?

Why do complex conversations take so much time?

David

To shift practice, thinking has to shift first. This requires the negotiation of time and convincing. Conversations, as interaction and engagement, may not encompass the same spirit of generosity and care that talanoa or talatalanoa does.

Sonia

The shift is most important, aided by considering which values inform our practice and behaviour in situations, particularly those we find challenging. It is important that time spent on shifting is valued and prioritised, and if we want true shift to occur it must come from the heart; this is not a quick thing but a commitment to lifelong learning, and very rewarding learning!

What are the risks and rewards?

\section{David}

Complex conversations are often seen as defiant behaviour. I don't see complex conversations as being defiant, but rather the beginning to generative talatalanoa which is associated with learning moments and encounters that are initially risky yet potentially rewarding. Therefore, if we value the community or communities we operate in within higher education, we engage in negotiation and develop a willingness to share with them our comforts and discomforts for the benefit of the community. As part of the MOANAed community within the University of Auckland's Faculty of Education and Social Work, Sonia and I, along with other alumni have positioned ourselves together (see Baice et al., 2021). We have confronted risks and rewards working together to drive Pacific Indigenous 
knowledge and research within New Zealand education. At the University of Waikato, I am part of several learning communities: one with early career scholars in the Te Kura Toi Tangata (School of Education) and another with Pacific academic and professional staff at the university. Talatalanoa guided by the principles of faka'apa'apa (respect), loto toka' $i$ (care), and loto-fie-foaki (generosity) allows for the difficult yet generative conversations to take place which are based on growth and development.

\section{Sonia}

The risks and rewards can be both visible and invisible, yet I think the invisible risks are the most dangerous because they are either implicit or passive, particularly in relation to conversations that are second-hand interpretations and occur away from those who are instigating these complex conversations. Furthermore, in contexts that prioritise outputs, resource production of tangible 'things' trying to describe the value of internal shifts can be dismissed as unimportant and a waste of time, thus we return to our earlier talatalanoa about valuing different knowledges. If we are rewarded for tangible and transactional practice, behaviour shifts in engaging in Pacific contexts and ways of being are perhaps not as measurable, especially if most who witness them aren't able to discern anything different - yet, for those who do understand, seeing shifts in practice is exciting and encouraging.

\section{Conclusion}

Havea (2020) reminds us that our vulnerabilities, even as educators and academics in higher education, need to be negotiated and released if we are to experience emancipation. By utilising talatalanoa, we engaged in critical reflection through ongoing and generative dialogue and writing that aided the unpacking of what we mean by complex conversations within university settings. Positioning Pacific/Moana (Oceania) and non-Pacific together in the sensemaking through talatalanoa has provided ways to negotiate and mediate complex conversations. If we are not open to articulating the challenges and concerns with competing knowledge systems linked to Pacific Indigenous knowledge and dominant Western knowledge, we risk perpetuating systemic processes and practices that further marginalise Pacific ways of being and knowing that can lead to useful possibilities within higher education.

\section{References}

Baice, T., Lealaiauloto, B., Meiklejohn-Whiu, S., Fonua, S. M., Allen, J. M., Matapo, J., Iosefo, F., \& Fa'avae, D. (2021). Responding to the call: Talanoa, va/vā, early career network, and enabling academic mobilities and pathways in higher education. Higher Education Research \& Development, 40(1), 75-89.

Bishop, R., Berryman, M., Cavanagh, T., \& Teddy, L. (2007). Te Kotahitanga Phase 3 whanaungatanga: Establishing a culturally responsive pedagogy of relations in mainstream secondary school classrooms. Ministry of Education. 
Fa'avae, D. T. M. (2021). Vā and veitapui as decolonial potential: ongoing talatalanoa, reimagining doctoral being and becoming. In C. Badenhorst, B. Amell \& J. Burford (Eds.), Re-imagining Doctoral Writing. University Press of Colorado. (forthcoming)

Fa'avae, D. T. M., Tecun, A., \& Siu'ulua, S. (2021). Talanoa vā: indigenous masculinities and the intersections of indigeneity, race, and gender within higher education. Higher Education Research \& Development. https://doi.org/10.1080/07294360.2021.1882402

Fonua, S. M. (2020). Lalanga ha kaha'u monu'ia - Helping science educators to embed indigenous knowledge, values, and culture in their courses for Māori and Pasifika science student success. MAl Journal, 9(1), 49-58.

https://doi.org/10.20507/MAIJournal.2020.9.1.6

Havea, J. (2020). Tell us. In J. Havea, \& S. Burns (Eds.), Vulnerabilities and resilience: Body and liberating theologies (Theology in the Age of Empire), pp. 1-12. The Rowman \& Littlefield Publishing Group Ltd.

Siope, A. (2013). A culturally responsive pedagogy of relations: coming to understand. Waikato Journal of Education, 18(2), 37-50.

Suaalii-Sauni, T. (2017). Va and kaupapa Māori. In T. Hoskins \& A. Jones (Eds.), Critical Conversations in Kaupapa Māori (pp. 168-171). Huia.

Thaman, K. H. (1995). Concepts of learning, knowledge and wisdom in Tonga, and their relevance to modern education. Prospects 25, 723-733. https://doiorg.ezproxy.auckland.ac.nz/10.1007/BF02334147

David Taufui Mikato Fa'avae is the son of Sio Milemoti and Fatai Onevai Fa'avae. He is currently lecturer in Pacific Education at the University of Waikato.

Email: david.faavae@waikato.ac.nz

ORCiD: https://orcid.org/0000-0002-6141-961X

Sonia M. Fonua is Pāpālangi (lea faka Tonga/Tongan language for being of European ancestry), born and raised in Aotearoa/New Zealand. She is currently a Professional Teaching Fellow in the School of Environment, Faculty of Science, University of Auckland.

Email: s.fonua@auckland.ac.nz

ORCiD: https://orcid.org/0000-0001-6626-6715 